\title{
STUDIES ON BREDININ. I
}

\author{
ISOLATION, CHARACTERIZATION AND BIOLOGICAL PROPERTIES*
}

\author{
Kimio Mizuno, Masatoshi Tsujino, Masaki Takada, Mitsuo Hayashi, \\ Kiyoo Atsumi, Katsumi Asano and Tetsuo Matsuda \\ Research Laboratories, Toyo Jozo Co., Ltd., Ohito, Shizuoka, Japan
}

(Received for publication June 6, 1974)

\begin{abstract}
Bredinin, $\mathrm{C}_{9} \mathrm{H}_{13} \mathrm{~N}_{3} \mathrm{O}_{6}$, is a novel imidazole nucleoside with an immunosuppressive activity. It was isolated from the culture filtrate of Eupenicillium brefeldianum M2166 by means of ion-exchange or partition chromatography. Bredinin shows selective cytotoxicity against L5178Y cells derived from malignant lymphoma of the mouse. As an immunosuppressant, it has favorable characteristics, namely, a potent activity, low acute toxicity, and a slight effect on a decrease of peripheral leukocytes. Bredinin inhibits the growth of vaccinia virus but not that of bacteria or fungi except for Candida albicans in vitro.

Slight prolongation in the survival period of mice inoculated with lymphatic leukemia L1210 was observed by intraperitoneal injection of bredinin, however, it was not effective on P388 leukemia or EHRLICH ascites tumor.
\end{abstract}

During our screening for new antibiotics, a fungal culture produced an antibiotic partially active against Candida albicans. The antibiotic was isolated and named bredinin. The producing organism was isolated from a soil sample collected at Hachijo, Tokyo, and designated to M-2166. It was classified as Eupenicillium brefeldianum ${ }^{1)}$ from cultural characteristic or microscopic observation.

Bredinin is a new member of the imidazole nucleoside series elucidated by X-ray analysis (Fig. 1). Although bredinin was primarily isolated as an antibiotic, its efficacy in experimental candidiasis of mice was not observed. On extensive pharmacological studies, bredinin was found to have a potent immunosuppressive activity.

The isolation, characterization and biolo-

Fig. 1. Structure of bredinin

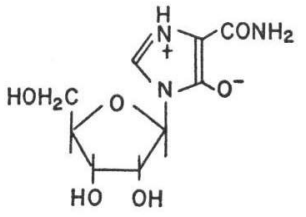
gical properties of bredinin are presented in this paper.

\section{Fermentation and Isolation}

Bredinin was produced in a medium (adjusted to $\mathrm{pH} 6.5$ ) containing $4.0 \%$ glucose, $2.0 \%$ peptone, $2.0 \% \mathrm{NaNO}_{3}, 0.2 \% \mathrm{KH}_{2} \mathrm{PO}_{4}$ and $0.02 \% \mathrm{MgSO}_{4} \cdot 7 \mathrm{H}_{2} \mathrm{O}$.

Two-hundred liters of sterilized medium in a stainless steel fermenter was inoculated with 2 liters of a seed culture. The cultivation was performed at $26^{\circ} \mathrm{C}$ for 90 hours with aeration (200 liters/min.) and agitation (250 r.p.m.). The activity of bredinin was assayed by an agar diffusion method using Candida albicans as the test organism in a modified SABouraud's-glucose

* This report was presented at the 189th meeting of the Japan Antibiotics Research Association, September 21, 1973. 
medium involving $0.001 \%$ bromophenol blue adjusted to $\mathrm{pH} 5.0$. The harvested broth was filtered with filter aid. The filtrate (170 liters; potency, $350 \mathrm{mcg} / \mathrm{ml}$ ) was adjusted to $\mathrm{pH} 10$ with $50 \% \mathrm{NaOH}$ and passed through a column of Amberlite IRA-411 $(\mathrm{OH}, 50$ liters). After the column was washed with water, bredinin was eluted with $2.0 \%$ aqueous acetic acid. The active eluates were combined and concentrated in vacuo to oily syrups followed by precipitation with acetone. The precipitate was chromatographed on a silica gel column (5 liters, 8.0 $\mathrm{cm}$ in diameter) developed with $n$-BuOH-acetic acid-water, 10:1:2. The active fractions were collected and evaporated to dryness. Further purification was made by DEAE Sephadex A-25 column ( 2 liters, $5.0 \mathrm{~cm}$ in diameter) developed with $0.1 \mathrm{~m}$ pyridine acetate buffer ( $\mathrm{pH} 6.0$ ).

The fractions giving positive test with $\mathrm{FeCl}_{3}$ solution were collected and concentrated under reduced pressure. To the concentrate, a half or equal volume of acetone was added and it was left overnight at $5{ }^{\circ} \mathrm{C}$. Colorless crystals $(30 \mathrm{~g})$ of bredinin were obtained.

\section{Physico-Chemical Properties}

Bredinin is a water-soluble, weakly acidic substance. Bredinin is stable at acidic or alkaline $\mathrm{pH}$ (Table 1).

Physical and chemical properties are listed in Table 2. Ultraviolet and infrared spectra of bredinin are given in Fig. 2 and Fig. 3 respectively. The n.m.r. spectrum in dimethyl sulfoxide (internal reference: tetramethylsilane) is shown in Fig. 4. The signals at $\delta$ $3.58(2 \mathrm{H}), \quad 3.90(\mathrm{H}), 4.08(\mathrm{H}), 4.40(\mathrm{H})$ and $5.53(\mathrm{H})$ were assigned to the protons on $\mathrm{C}^{\prime}$, $\mathrm{C}^{\prime}, \mathrm{C}^{\prime}, \mathrm{C}^{\prime}$ and $\mathrm{C}^{\prime}$ of ribose respectively

Table 1. Stability of bredinin

\begin{tabular}{c|c|c}
\hline \multirow{2}{*}{$\mathrm{pH}$} & \multicolumn{2}{|c}{ Residual activity $(\%)$} \\
\cline { 2 - 3 } & $60^{\circ} \mathrm{C} 30 \mathrm{~min}$. & $100^{\circ} \mathrm{C} 30 \mathrm{~min}$. \\
\cline { 2 - 3 } 2.0 & 92 & 79 \\
4.0 & 100 & 81 \\
6.0 & 100 & 86 \\
8.0 & 100 & 89 \\
\hline $0.5 \mathrm{~N} \mathrm{HCl}$ & 90 & 66 \\
$0.5 \mathrm{~N} \mathrm{NaOH}$ & 90 & 76 \\
\hline
\end{tabular}

Table 2. Physico-chemical properties of bredinin

\begin{tabular}{|c|c|}
\hline Melting point & $200^{\circ} \mathrm{C}$ (decomp.) \\
\hline$[\alpha]_{27}^{\mathrm{D}}$ & $-35^{\circ}\left(c \quad 0.8, \mathrm{H}_{2} \mathrm{O}\right)$ \\
\hline Analysis & $\begin{array}{l}\text { Calcd. for } \mathrm{C}_{8} \mathrm{H}_{13} \mathrm{~N}_{3} \mathrm{O}_{6}(\mathrm{MW} \mathrm{259.22)} \\
\qquad \mathrm{C} \mathrm{41.70,H} \mathrm{5.06,} \mathrm{N} \mathrm{16.21,} \mathrm{O} 37.03\end{array}$ \\
\hline $\mathrm{pKa}$ & $\begin{array}{l}\text { Found: C } 41.57, \mathrm{H} 4.91, \mathrm{~N} 16.38, \mathrm{O} 36.40 \\
6.75 \text { (titration eq. } 265 \text { ) }\end{array}$ \\
\hline UV maxima & $\begin{array}{l}\text { in } \mathrm{H}_{2} \mathrm{O}: 245 \mathrm{~nm}\left(\mathrm{E}_{1 \mathrm{~cm}}^{1 \%} 250\right), 279 \mathrm{~nm}\left(\mathrm{E}_{1 \mathrm{~cm}}^{1 \%} 580\right) \\
\text { in } 1 \mathrm{~N} \mathrm{HCl}: 245 \mathrm{~nm}\left(\mathrm{E}_{1 \mathrm{~cm}}^{1 \%} 260\right), 281 \mathrm{~nm}\left(\mathrm{E}_{1 \mathrm{~cm}}^{1 \%} 495\right) \\
\text { in } 1 \mathrm{~N} \mathrm{NaOH}: 277 \mathrm{~nm}\left(\mathrm{E}_{1 \mathrm{~cm}}^{1 \%} 660\right)\end{array}$ \\
\hline Color reaction & 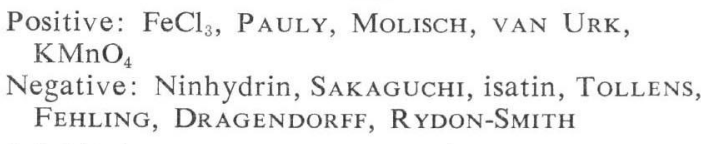 \\
\hline Solubility & $\begin{array}{l}\text { Soluble in water. } \\
\text { Slightly soluble in lower alcohols } \\
\text { Insoluble in most organic solvents }\end{array}$ \\
\hline PPC & $\begin{array}{l}\text { Rf } 0.52 \text { ( } n \text {-Butanol-AcOH-pyridine-water, } \\
\qquad 15: 3: 10: 12)\end{array}$ \\
\hline TLC (Kieselgel G) & Rf 0.45 (n-Butanol-AcOH-water, $3: 1: 1)$ \\
\hline
\end{tabular}




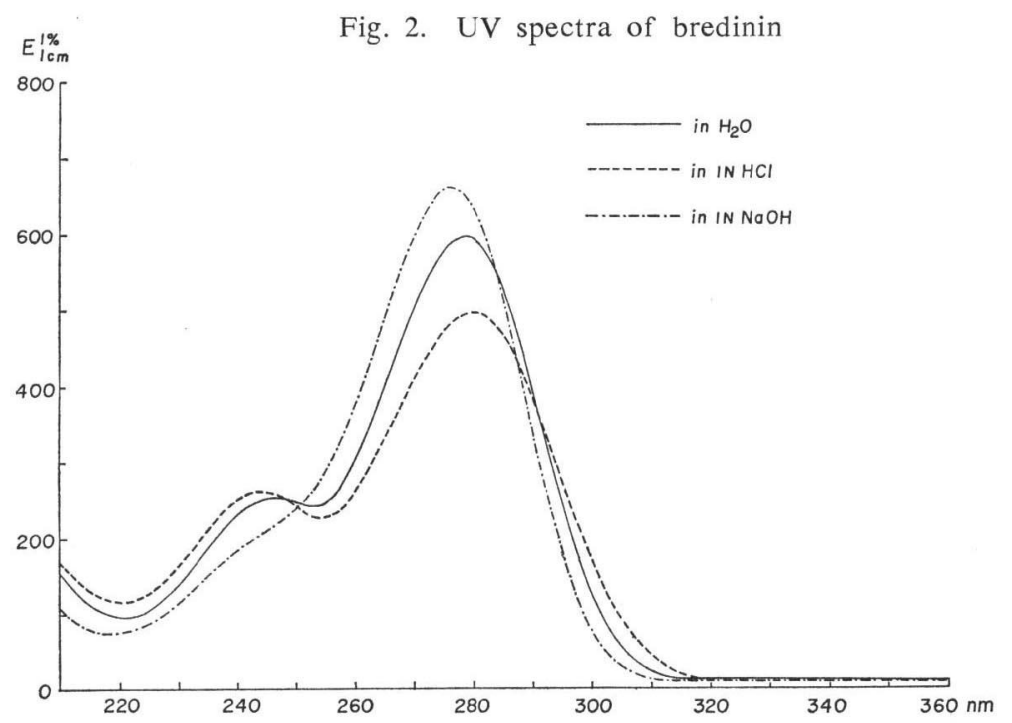

Fig. 3. IR spectrum of bredinin $(\mathrm{KBr})$

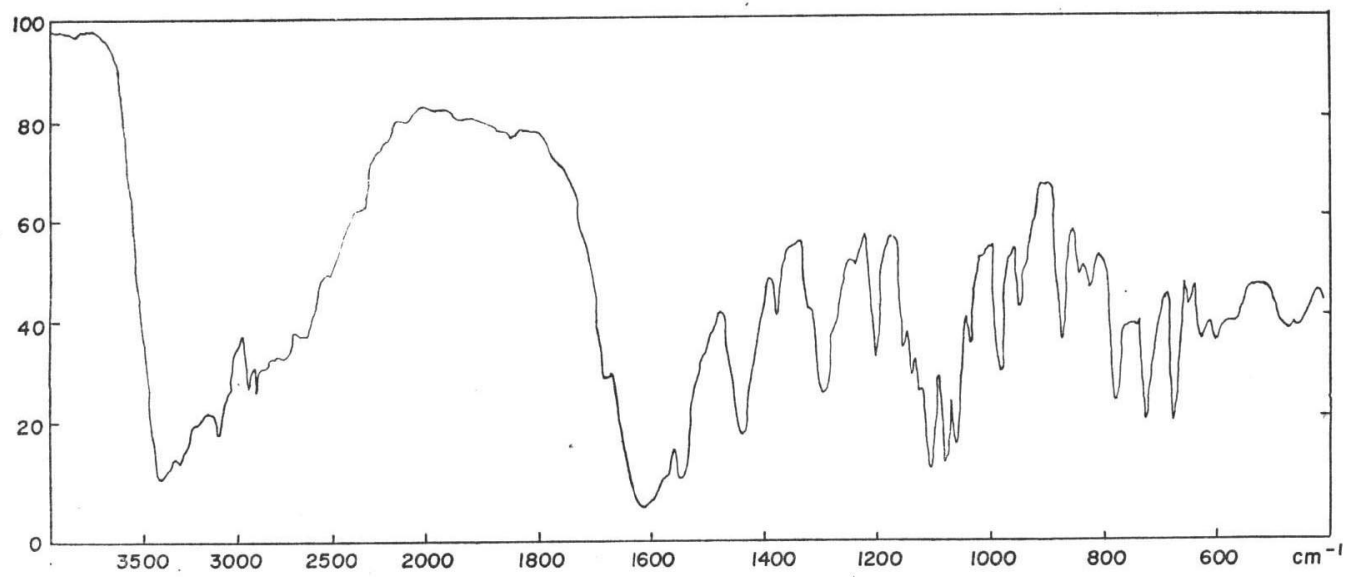

by means of double spin decoupling. The sharp singlet at $\delta 8.29(\mathrm{H})$ is due to an aglycone moiety. The broad peaks at $\delta 5.5(4 \mathrm{H})$ and at $6.9(2 \mathrm{H})$ are considered to be $\mathrm{NH}$ or $\mathrm{OH}$ which disappeared with $\mathrm{D}_{2} \mathrm{O}$.

When bredinin was hydrolized with $6 \mathrm{~N} \mathrm{HCl}$ at $105^{\circ} \mathrm{C}$ for 20 hours in a sealed tube, 0.7 mole of glycine was liberated.

The chemical structure was elucidated by X-ray analysis as 4-carbamoyl-1-ribofuranosylimidazolium-5-olate ${ }^{2)}$.

\section{Biological Properties}

1. Antimicrobial Activity

Bredinin is substantially inactive against microorganisms except for Candida albicans as indicated in Table 3. As seen in the table the partial activity of bredinin against C. albicans 
Fig. 4. NMR spectrum of bredinin $\left(100 \mathrm{MHz}\right.$, in DMSO-d $\left.\mathrm{d}_{6}\right)$

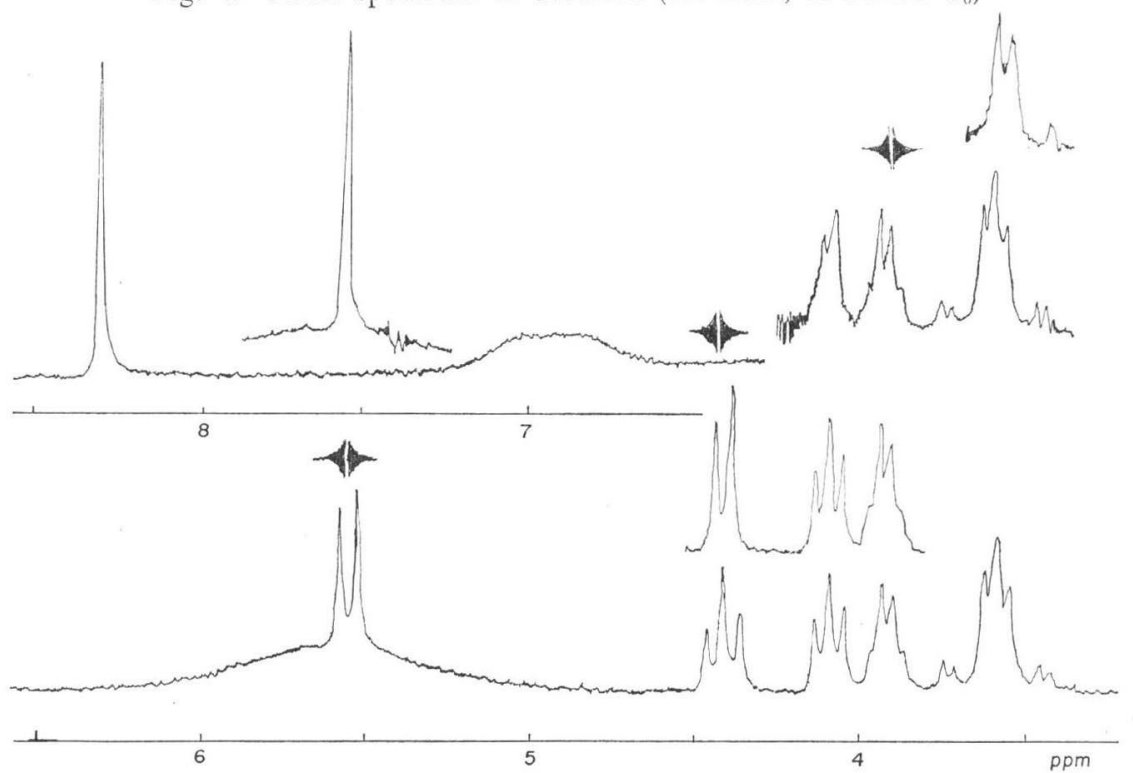

Table 3. Antimicrobial spectrum of bredinin in agar dilution method

\begin{tabular}{|c|c|c|}
\hline Test organism & Medium & $\operatorname{MIC}(\mathrm{mcg} / \mathrm{ml})$ \\
\hline Staphylococcus aureus FDA 209P & Nutrient & $>1,000$ \\
\hline Bacillus subtilis PCI 219 & " & $1,000 \sim 250$ \\
\hline Sarcina lutea & " & $>1,000$ \\
\hline Escherichia coli $\mathrm{NIHJ}$ & " & $>1,000$ \\
\hline Klebsiella pneumoniae & " & $>1,000$ \\
\hline Pseudomonas aeruginosa & " & $>1,000$ \\
\hline Mycobacterium 607 & " & $>1,000$ \\
\hline Candida albicans 1 & SABOURAUD'S & $1,000 \sim 16$ \\
\hline$" \prime \prime 2$ & " & $1,000 \sim 4$ \\
\hline$" 3$ & " & $1,000 \sim 16$ \\
\hline " ATCC 7491 & " & $1,000 \sim 8$ \\
\hline " krusei & " & $>1,000$ \\
\hline " parakrusei & $"$ & $>1,000$ \\
\hline "tropicalis & " & $>1,000$ \\
\hline " pseudotropicalis & " & $>1,000$ \\
\hline " guilliermondii ATCC 7335 & " & $>1,000$ \\
\hline " pulcherrima АТCC 7475 & " & $>1,000$ \\
\hline
\end{tabular}

Incubation: Nutrient agar, $37^{\circ} \mathrm{C}, 18$ hours; SAbouraud's agar, $30^{\circ} \mathrm{C}, 18$ hours

was specific among candida species. Against other fungi unlisted in the table such as Saccharomyces cerevisiae, Trichophyton asteroides, Aspergillus fumigatus and Penicillium chrysogenum, it showed no inhibitory activity. Attempts to protect against experimental candidiasis of mice with bredinin were unsuccessful.

\section{Cytotoxic Activity}

Cytotoxicity of bredinin for some tissue culture cells was examined and the growth in- 
Fig. 5. Growth inhibitory effect of bredinin on various cells
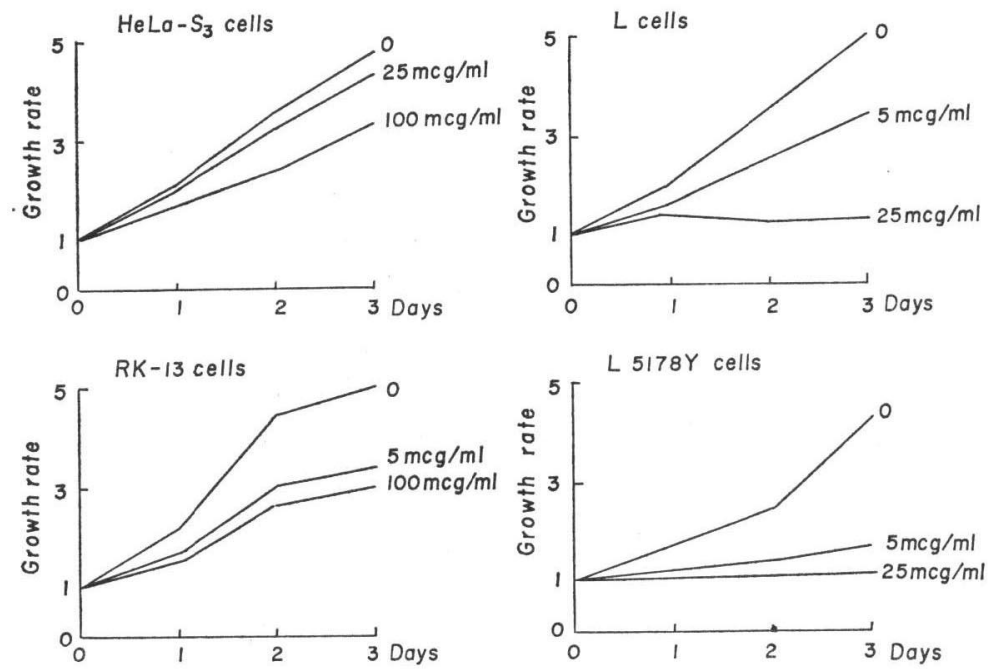

Fig. 6. Immunosuppressive activities of bredinin and imuran in mice

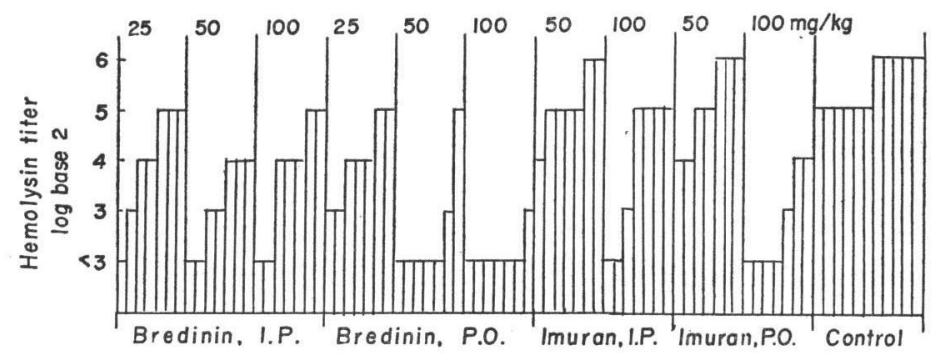

SRBC was injected on the day 0 . The hemolysin titers were determined on the day 4. Drugs were administered once a day on the day 0 to 3 .

Fig. 7. Effect on secondary immune response

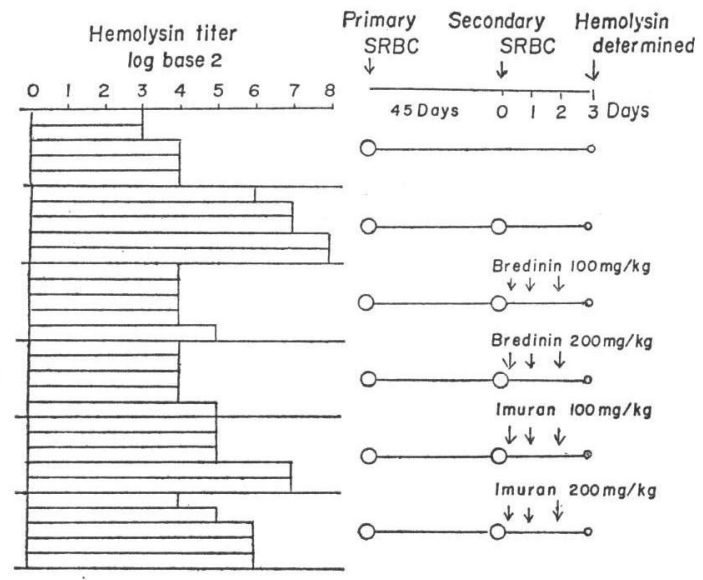

hibitory feature are illustrated in Fig. 5. The results sugggest that bredinin has a selective cytotoxicity to lymphoma cell line L5178Y cells.

\section{Antiviral Activity}

The antiviral activity was assayed in vitro. The cells, treated with various concentration of bredinin, were challenged with virus, and after 72 hours, virus-induced cytopathogenic effects as a parameter for antiviral evaluation were determined by microscopic examination. The systems of virus-cells employed in this experiment were as follows: Herpes simplex virus (Type 1, MEF1)-HeLa $\mathrm{S}_{3}$, Polio virus

(Type 1 Sabin)-HeLa $\mathrm{S}_{3}$, HVJ (Fushimi strain)-L, and Vaccinia-mouse embryo primary culture 
Fig. 8. Life prolongation on L1210 by intraperitoneal injection of bredinin

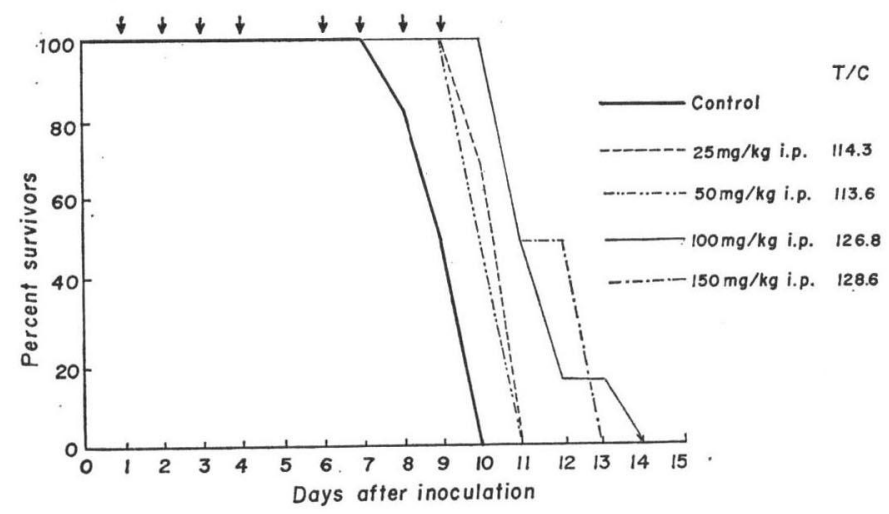

cells.

Bredinin prevented the proliferation of vaccinia virus at a concentration of more than $0.8 \mathrm{mcg} / \mathrm{ml}$ but did not inhibit others.

When bredinin was removed from the medium after treatment for 24 hours the antivaccinia activity disappeared. From this result, bredinin is considered to have not induced interferon.

\section{Immunosuppressive Activity}

The immunosuppressive activity of bred-
Fig. 9. Effect on the number of peripheral leukocytes in mice

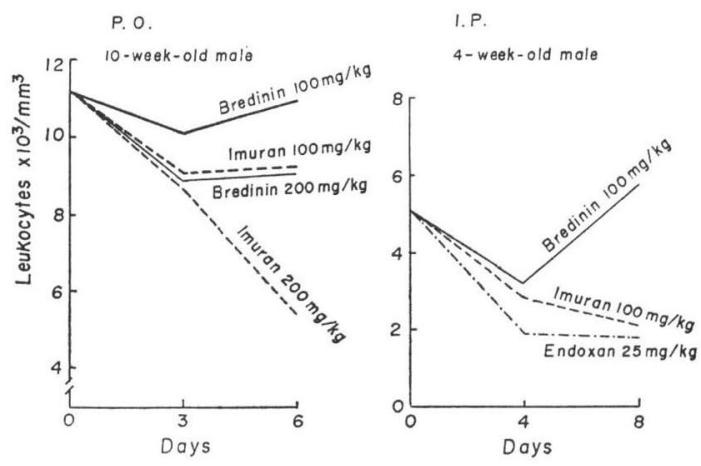
inin was assayed in comparison with azathioprine (Imuran) ${ }^{3)}$ which has been widely used as a major drug combined with corticosteroids in immunosuppressive therapy ${ }^{4}$.

After a sheep red blood cell preparation (SRBC) was injected in mice, the drugs were administered intraperitoneally or orally once a day on days 0 to 3 and the hemolysin produced was measured on day $4^{5}$. As shown in Fig. 6 , bredinin was more active than azathioprine and showed a potent activity in oral administration.

The effect on the secondary immune response are also examined by oral administration in mice. The experimental schedule and the effect are summarized in Fig. 7. Bredinin suppressed hemolysin production to the same extent as the control group without secondary immunization.

\section{Antitumor Activity}

Bredinin showed a little effect on the life prolongation of mice inoculated with lymphatic leukemia L1210 as shown in Fig. 8, but was not active against EHRLICH ascites and P388 tumor.

\section{Toxicity}

The acute toxicity of bredinin in mice is very low, therefore the single dose $L_{50}$ was 
not calculated. The mice injected with $5,000 \mathrm{mg} / \mathrm{kg}$ intraperitoneally or $1,500 \mathrm{mg} / \mathrm{kg}$ intravenously of bredinin did not result in lethal for the period of 9-day observation.

The above doses were limit for injection due to the solubility.

When bredinin was injected successively once a day by intraperitoneal route in mice, it showed slight influence on a decrease of peripheral leukocytes, which is the most troublesome side effect in immunosuppressive therapy. ${ }^{4)}$ A comparative data of bredinin with azathioprine and cyclophosphamide (Endoxan $)^{6)}$ is given in Fig. 9.

\section{Discussion}

Bredinin is clearly distinguished from other antibiotics and nucleosides by its chemical and physical properties as described above. The taxonomical name, Eupenicillium brefeldianum, had been given to the perfect stage of Penicillum brefeldianum by ScotT et al. ${ }^{11}$ in 1967 on the basis of the concept to prefer the perfect stage.

Penicillium brefeldianum was reported to produce palitantin, ${ }^{7,8)}$ frequentin, ${ }^{7,8)}$ griseofulvin, ${ }^{7)}$ fulvic acid, ${ }^{7)}$ brefeldin A and B. ${ }^{8)}$ Eupenicillium brefeldianum M-2166 strain was also found to produce brefeldin $\mathrm{A}$ as a minor component in bredinin fermentation.

As a naturally occurring imidazole nucleoside, 5-amino-4-imidazole carboxamide riboside (AICA-riboside), ${ }^{\theta)}$ an intermediate of purine nucleoside biosynthesis, is well known but it has not been reported to have any biological activity. Therefore bredinin is the first discovered imidazole nucleoside with biological activity.

On account of the structural relationship between the above nucleosides, it is suggested that bredinin is probably synthesized through a bypath of the pathway in purine nucleoside or nucleotide synthesis.

The chemical structure in the solid state is zwitterionic, however, when bredinin was subjected to potentiometric titration according to the procedure of PARKe et al., ${ }^{10)}$ it showed only one dissociation group giving pK'a 6.75. Because bredinin was not titrated with an acid, the titrable function was proton-donating.

The ultraviolet spectrum of bredinin was substantially unchanged in acidic or alkaline solution. On the other hand, pyrazomycin which resembles bredinin in structure and has a pKa value of 6.7, presumably due to the dissociation of the enol in the molecule, exhibits a bathochromic shift compatible with reaction of the enol function in alkaline solution. ${ }^{11}$ Therefore in an aqueous solution, it is presently not known whether or not the zwitterionic structure is retained and what functional group is titrable.

Anti-candida activity of bredinin is partial and this is quite similar to those of pyrazomycin and aristeromycin ${ }^{12}$ ) which are recently reported nucleoside antibiotics. The failute to protect against systemic candidiasis in mice with bredinin depends probably on not only its weak activity but the immunosuppressive activity; as a good example, azathioprine has been used as a subsidiary agent against infection in experimental mycosis. ${ }^{13)}$

Many clinically severe diseases such as collagen diseases, blood autoimmune diseases, specific autoimmune diseases located in a particular organ and organ transplantation are all thought to participate in cellular immunity. These diseases have been subjected to immunosuppressive therapy with antimetabolites, alkylating agents, antibiotics, corticosteroids, plant alkaloids or anti-lymphocyte globulin ${ }^{4}$

Immunosuppressive activity of bredinin is thought to result from function as an antimetabolite due to its chemical structure, and the mechanism of action is now under investigation.

Among antimetabolites, 6-mercaptopurine, azathioprine, or 8-azaguanine have been clinically used, however, the dosages have been restricted because of side effects, especially bone marrow damage with possible irreversible pancytopenia. ${ }^{14,15)}$

In respect to the side effects, bredinin is considered to be a safer substance than other 
antimetabolites, from experiment concerning the effect on peripheral leukocyte number after successive administration in mice. This is an interesting characteristic of bredinin. Detailed studies on immunosuppression or toxicology of it are in progress.

Numerous antibiotics have been hitherto reported but the majority were abandoned because of lack of practical usefulness as antibiotics. As described above, originally bredinin was isolated as an antibiotic and further pharmacological studies led us to discover other physiological activity than antibiotic activity. This draws attention to the possibility of finding novel or unique properties hidden by antibiotic activity, from among the abandoned antibiotics.

\section{Acknowledgment}

The authors wish to thank Prof. N. IsHida, Tohoku University, for his helpful suggestions, Dr. Y. Sakurai, Cancer Institute, for antitumor test and Dr. K. Hirayama, Fuji Film Co., Ltd., for his kind suggestion respecting nomenclature. The authors are also indebted to Dr. JoHN G. WhitNey, The Lilly Research Laboratories, for his kind supply of pyrazomycin sample.

\section{References}

1) Stolk, A.C. \& De B. Scott: Studies on the genus Eupenicillium Ludwig. I. Taxonomy and nomenclature of Penicillia in relation to their sclerotioid ascocarpic status. Persoonia 4: 391 405, 1967

2) Yoshioka, H.; K. Nakatsu, M. Hayashi \& K. Mizuno: The molecular structure of bredinin. Tetrahedron Letters (in press)

3) Hitchings, G.H. \& G.B. Elion: Purine derivatives. U.S. Patent 3,056,785, Oct. 2, 1962

4) Kuroyanagi, T.; Y. Otaka \& T. Matsuhashi: Immunosuppressive therapy. pp 29 47, Igaku Shoin, Tokyo, 1971

5) Gray, G.D.; M.M. Mickelson \& J.A. Grim: The immunosuppressive activity of ara-cytidine. I. Effect of antibody-forming cells and humoral antibody. Transplantation 6: 805 817, 1968

6) Arnold, H.; F. Bourseaux \& N. Brock: Chemotherapeutic action of cyclic nitrogen mustard phosphamide ester (B518-ASTA) in experimental tumor of rat. Nature 181: 931, 1958

7) Shibata, S.; S. Natori \& S. Udagawa: List of fungal products. pp $22 \sim 57$, University of Tokyo Press, 1964

8) Haerri, E.; W. Loefflfr, H.P. Sigg, H. Staehelin \& Ch. Tamm: Isolation of new metabolic products from Penicillium brefldianum. Helv. Chim. Acta 46: 1235 1243, 1963

9) Greenberg, G. R.: Isolation of 4-amino-5-imidazolecarboxamide riboside from the culture medium of sulfonamide-inhibited Escherichia coli. J. Am. Chem. Soc. 74: 6307 6308, 1952

10) PARKe, T.V. \& W.W. DAvis: Use of apparent dissociation constants in qualitative organic analysis. Anal. Chem. 26: 642 645, 1954

11) Suhadolnik, R.K.: Nucleoside Antibiotics. pp. 390 392, Wiley-Interscience, New York, 1970

12) Kusaka, T.; H. Yамamoto, M. Shibata, M. Muror, T. Kishi \& K. Mizuno: Streptomyces citricolor nov. sp. and a new antibiotic aristeromycin. J. Antibiotics 21: 255 263, 1968

13) Linquist, J.A.; S. Rabinovich \& I.M. Sмith: 5-Fluorocytosine in the treatment of experimental candidiasis in immunosuppressived mice. Antimicr. Agents \& Chemoth. 4: 58 61, 1973

14) Lahoda, F.: Moderne Gesichtspunkte der immunsuppressiven Therapie. Med. Monatsschr. 25: $61 \sim 65,1971$

15) Decker, J.L.: Toxicity of immunosuppressive drugs in man. Arthritis Rheum. 16: 89 91, 1973 